\title{
Single-Use Paper-Based Hydrogen Fuel Cells for Point-of-Care Diagnostic Applications
}

\author{
J. P. Esquivel ${ }^{a, b_{*}}$, J. R. Buser ${ }^{b}$, C. W. Lim ${ }^{b}$, C. Domínguez ${ }^{c}$, S. Rojas ${ }^{c}$, P. Yager ${ }^{b}$ and N. Sabatéa,d
}

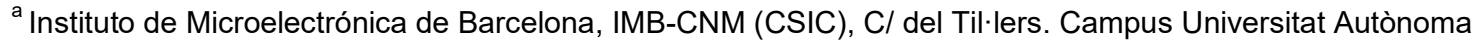 \\ de Barcelona (UAB), 08193 Bellaterra, Barcelona, SPAIN, E-mail: juanpablo.esquivel@csic.es \\ ${ }^{\mathrm{b}}$ Department of Bioengineering, University of Washington, Seattle, WA 98195, USA \\ ${ }^{\mathrm{c}}$ Instituto de Catálisis y Petroleoquímica, ICP (CSIC), C/ Marie Curie 2, 28049, Cantoblanco, Madrid, Spain \\ ${ }^{d}$ Catalan Institution for Research and Advanced Studies (ICREA), Passeig Lluís Companys 23, 08010 \\ Barcelona, Spain
}

\begin{abstract}
This work demonstrates a stand-alone power source that integrates a paper-based hydrogen fuel cell with a customized chemical heater that produces hydrogen in-situ upon the addition of a liquid. The presented approach operates by capillary action and takes advantage of the hydrogen released as a by-product of an exothermic reaction used in point-of-care diagnostics. The paperbased fuel cell produces a maximum power of $25.8 \mathrm{~mW}\left(103.2 \mathrm{~mW} \mathrm{~cm}^{-2}\right)$, which is suitable for powering a diversity of electrical devices such as commercially available digital pregnancy tests and glucometers. While device shape and dimensions can be customized, here it is shown that the fuel cell can be designed in a compact form factor and footprint comparable to a lateral flow test while providing a remarkable power output. This approach holds great promise for powering portable diagnostics, as the generated electric power could enable device functionalities required for advanced assays, such as device timing, actuation, and signal quantification. Part of the same liquid sample that is to be analyzed (urine, saliva, water, etc) could be used to trigger the hydrogen generation and start the fuel cell operation.
\end{abstract}

Keywords: hydrogen fuel cell, paper microfluidics, point-of-care, diagnostics, lateral flow

\section{Introduction}

Lateral flow tests have dominated the point-of-care diagnostics market for decades due to their rapid response, robustness, ease of use and visual indication without external instrumentation. However, they lack quantitation and frequently require additional sample handling steps before use. Paper microfluidics technology has recently enabled quantitative or semi-quantitative analysis and integrate microfluidic functions in the same device without adding complexity to the user.[1] The ideal portable diagnostic device for the point-of-care would provide an unambiguous assay result without any external instrumentation. A crucial component to achieve this vision is a power source that eliminates dependence on power grids and that could be compatible with the lateral flow assay manufacture, storage, usage and end of life. In this respect, some paper-based energy sources with different operating principles have been proposed to deliver electric power to this new generation of paper diagnostics.[2] Recent review articles summarize these energy generation and storage approaches.[3-6] Among these approaches, paper-based fuel cells stand out as promising candidates to fulfill the energy requirements of portable tests. Built upon the benefits of microfluidic fuel cells, $[7,8]$ they do not require a polymer electrolyte membrane as they rely on laminar flow to separate the reactants. Additionally, the use of paper also eliminates the need of external pumps because reactants flow by capillary forces. Furthermore, a fuel cell design inspired by the simplicity and convenience of standard lateral flow test strips has been reported, which makes it suitable for manufacturing using the same mass production methods.[9] 
The paper fuel cells reported up to date have employed liquid or diluted fuels such as methanol,[9] formic acid,[10, 11] formate,[12-14] hydrogen peroxide,[15] glucose[16-22] or urea[23] and have been based on microbial,[23-25] enzymatic[16-21] or metallic catalysis.[9, 11-13, 15] Table S1 shows a performance comparison of relevant paper-based fuel cells found in the literature. Most of these fuel cells provide a lightweight, inexpensive and disposable portable power alternative with minimum environmental impact. However, even though the liquid fuels used in these devices offer a high theoretical specific energy, their efficiency in energy conversion is rather low. Consequently, the actual volumetric power densities provided are still insufficient to compete against commercially available alternatives, such as Li-ion coin cell batteries, so their use is limited to very low power demanding functions. In this regard, hydrogen has proved to be far more efficient than its liquid alternatives,[26-28] although its storage and handling poses complex hurdles to practical implementation in portable applications. The use of hydrogen usually requires specialized gas containers and additional equipment to control pressure and flow rate. All these ancillary components turn a potentially sleek and simple device into a bulky system, which causes a diminution in total energy density and results in an unfavorable competitor when compared to batteries.[29] Issues related to hydrogen storage and handling in portable formats have been solved by the use of reusable metal hydrides cartridges,[30, 31] some of which have eventually reached the market as portable USB chargers.[32, 33] Another commercial approach is based on the in situ generation of hydrogen from single-use disposable canisters containing aluminum, sodium silicide, sodium borohydride and other salts that react upon the addition of water providing electric energy for a short period of time.[34] This approach provides a convenient, safe and inexpensive method for storing and transporting hydrogen for portable applications.

This work takes this concept for hydrogen generation as the basis of developing paper-based hydrogen fuel cells as single use disposable power sources. The idea stems from interactions with an ongoing DARPA-funded project led by the University of Washington aimed at producing a pointof-care diagnostic device that required multiple controlled heating steps.[35] We have coupled the advantages of paper fuel cells with the $\mathrm{H}_{2}$ producing material that is used in isothermal nucleic acid amplification devices as an exothermic chemistry, i.e. the corrosion of magnesium iron particles.[3642] This chemistry is very convenient, as it, requires only the addition of water to achieve $100^{\circ} \mathrm{C}(\mathrm{a}$ reason why it has also been widely used to heat portable meals). During the course of the chemical reaction the magnesium is oxidized, releasing hydrogen gas as a byproduct, which previously was simply vented off to the atmosphere. These simple devices, originally designed to hold elevated temperatures, have inadvertently solved one of the critical challenges for portable hydrogen fuel cells: storage and release of hydrogen gas. This hydrogen is already being produced as a waste product for these devices and, as it will be shown here, building a fuel cell into the device can produce usable electricity from this waste product.

In this article a paper-based fuel cell using in situ generated hydrogen as the fuel is presented for the first time. The efficient catalysis of hydrogen results in the highest power output ever reported in a portable paper-based fuel cell, achieving a power density comparable to that delivered by commercial Li-ion coin cell batteries. This high performance is a result of the successful integration of the hydrogen-producing MgFe alloy, an effective fluid handling (comprising liquids transported by capillarity and gases through leak-proof conducts and chambers), and a convenient utilization of heat and hydrogen. The fuel cell dimensions, form factor and simplified user experience (just adding a liquid into a pad to activate it) are inspired in the most widely used diagnostic devices, i.e. lateral flow tests. This hydrogen fuel cell approach maintains the advantages of paper-based fuel cells. It operates via capillary forces without any moving parts, which enables simple and robust designs. It also requires no ancillary devices such as pumps, heaters or humidifiers. A paper strip blotted with liquid electrolyte acts as separator, which eliminates the need for a polymer electrolyte membrane. These devices can be inexpensively fabricated from widely available, low-cost materials already being used in the rapid diagnostic test industry. Additionally, the disposal pathway of the fuel cell can be similar to a lateral flow test, unlike a lithium ion battery, which requires special disposal considerations. While device shape and dimensions can be customized, here we show 
that the fuel cell can be designed in a form factor and footprint comparable to a lateral flow test while providing a remarkable power output, sufficient to run electrochemical or optical detection instrumentation, and sustain it for the duration of rapid tests diagnostics (typically 5-30 min).

The resulting paper-based hydrogen fuel cell holds great promise for powering portable diagnostics as the generated electric power could actually be used to enable the device functionalities required for advanced assays, such as device timing and actuation along with signal quantification. In this case, the same liquid sample that is to be analyzed (urine, saliva, water, etc.) could trigger the hydrogen generation and start the fuel cell operation.

\subsection{Device description}

The present device consists of two main parts, a hydrogen generator and an alkaline fuel cell that consumes the generated hydrogen to produce electrical power. Figure 1 shows a cross-section diagram of the paper-based hydrogen fuel cell, its components and its operation under the addition of an aqueous solution to the cellulose pad placed at one end of the device. After adding a liquid, capillary action carries the sample in two directions (Stage 1). On one side, the liquid travels down to the hydrogen reactor, dissolving the $\mathrm{NaCl}$ stored in the paper channel. The saline produced flows by capillarity towards the reaction chamber, triggering the magnesium-iron alloy ( $\mathrm{MgFe})$ exothermic reaction responsible for the $\mathrm{H}_{2}$ generation (Equation 1):

$$
\mathrm{Mg}+2 \mathrm{H}_{2} \mathrm{O} \rightarrow \mathrm{Mg}(\mathrm{OH})_{2}+\mathrm{H}_{2}+\text { Heat }
$$

A hydrophobic porous membrane placed on top of the MgFe reservoir confines the solids (MgFe and oxidation by-products) and liquid phases (saline solution) in a reaction chamber, whereas the generated gases (hydrogen and water vapor) flow freely towards the fuel cell (Stage 2). On the other side, the liquid travels through the upper paper channel, dilutes the $\mathrm{KOH}$ salt stored in a cellulose pad and then flows towards the fuel cell electrodes. The bottom electrode (anode) reacts with hydrogen coming from the MgFe reaction (Equation 2):

$$
2 \mathrm{H}_{2}+4 \mathrm{OH}^{-} \rightarrow 4 \mathrm{H}_{2} \mathrm{O}+4 e^{-}
$$

whereas the top fuel cell electrode (cathode) takes oxygen from air (Equation 3):

$$
\mathrm{O}_{2}+2 \mathrm{H}_{2} \mathrm{O}+4 e^{-} \rightarrow 4 \mathrm{OH}^{-}
$$

The overall fuel cell reaction is shown in Equation 4.

$$
2 \mathrm{H}_{2}+\mathrm{O}_{2} \rightarrow 2 \mathrm{H}_{2} \mathrm{O}
$$

Consequently, the electric energy production of the device will depend on the amount of $\mathrm{Mg}$ stored and rate in which it is converted into hydrogen. 

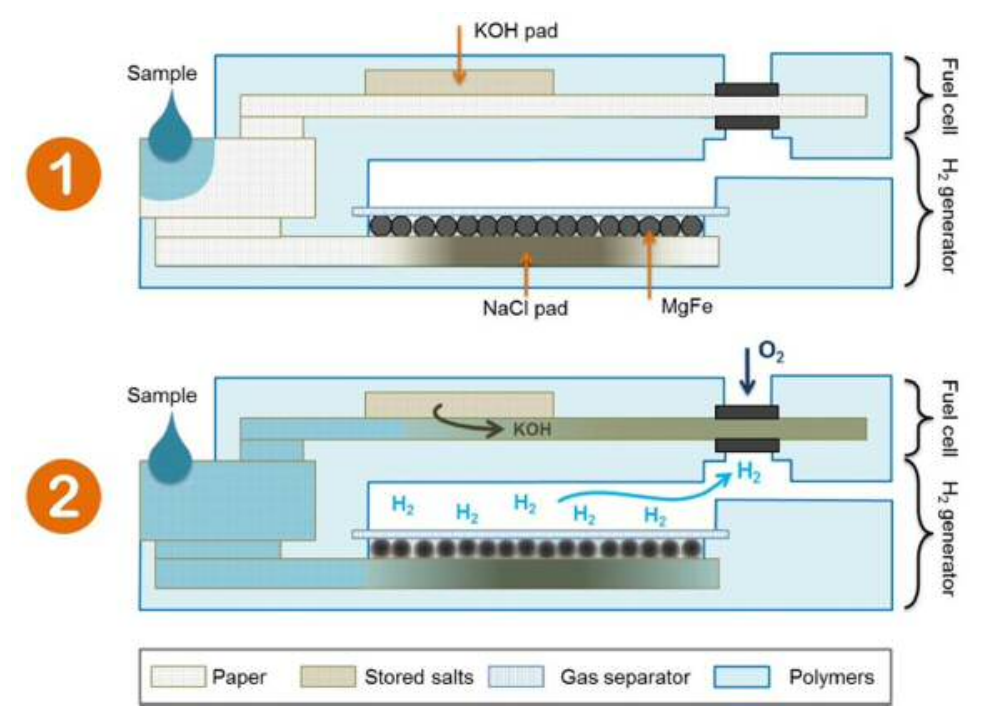

Figure 1. Cross-section diagram of paper-based hydrogen fuel cell and stages of operation.

\section{Experimental}

\section{Device fabrication.}

The paper and polymeric laminates comprising the device were designed in a CAD program (Autocad, Autodesk, San Rafael, CA, USA) and cut using a $\mathrm{CO}_{2}$ laser cutter (VLS3.60, Universal Laser Systems Inc., Scottsdale, AZ, USA). Most of the device assembly was done layer by layer using alignment jigs. The hydrogen generator is composed of several adhesive-backed Mylar laminates (Melinex, Fralock, Valencia, CA, USA) encapsulating an inlet cellulose pad (CFSP223000, Ahlstrom, Helsinki, Finland), a cellulose strip (CF10, GE Healthcare, Pittsburgh, PA, USA) and a reaction chamber containing 25-50 mg of MgFe alloy with a particle size of 400-450 $\mu \mathrm{m}$ (Luxfer Magtech, Cincinnati, OH, USA) covered by a hydrophobic porous membrane (21M, Porex, Fairburn, GA, USA). For reactors including $50 \mathrm{mg}$ of MgFe alloy, one of the Mylar laminates was substituted by a $1.5 \mathrm{~mm}$-thick PMMA layer and the reaction chamber containing the MgFe alloy was segmented in three parts. The fuel cell consists of a 5-mm wide paper strip (Fusion 5, GE Healthcare) and two 5-mm wide carbon paper electrodes (TGP-060, Toray, Japan) placed on top and bottom of the strip. The parts were held together using laser cut adhesive-backed Mylar laminates (Fralock). The thickness of the fuel cell was $0.7 \mathrm{~mm}$ and the entire assembly was $3.0 \mathrm{~mm}$. The electrodes yielded a fuel cell projected geometric active area of $0.25 \mathrm{~cm}^{2}$ and contained a catalyst loading of $1 \mathrm{mg} \mathrm{cm}^{-2} \mathrm{Pt}$ supported on Carbon Vulcan XC72 (Johnson Matthey, Royston, UK).

\section{Hydrogen generator and fuel cell characterization.}

After being cut to the desired dimensions $(4 \times 45 \mathrm{~mm})$, the cellulose strips were supplied with different amounts of a $24 \mathrm{wt} \% \mathrm{NaCl}$ solution and placed in a desiccator for at least 24 hours before device assembly and testing. Volumes of $400 \mu \mathrm{L}$ of water or $\mathrm{NaCl}$ solution were added to the inlet pad for each test. Temperature was recorded using a thin thermocouple inserted in the reaction chamber and recorded with a data acquisition system (OMB-DAQ-54, Omega Engineering, Stamford, CT, USA) and Personal DaqView software (Omega Engineering). The produced hydrogen was collected in a glass syringe connected to the generator outlet. In order to calculate the $\mathrm{H}_{2}$ flow rate against time, the volume of $\mathrm{H}_{2}$ gas produced in time was obtained. The overall reaction process was recorded using a webcam (Pro 9000 V-U0009, Logitech, Fremont, CA, USA) 
controlled by a time-lapse software (VideoVelocity, CandyLabs, Vancouver, BC, Canada) that saved images at a rate of 1 frame / 10 seconds. The times at which the $\mathrm{H}_{2}$ volume inside the syringe reached an integer value (every $1 \mathrm{~mL}$ ) were extracted from the recorded images and used to calculate the $\mathrm{H}_{2}$ flow rates. The hydrogen was produced in a vertical column from the same $\mathrm{MgFe}$ used for the fuel cell reactor. The fuel cell was fixed onto a plastic fitting that allowed the anode side to be exposed to hydrogen pumped at a controlled flow rate using a syringe pump (Model 100, KD Scientific Inc., Holliston, MA, USA). Temperature was controlled by placing the fuel cell on a hot plate covered by an isolating case. The temperature at the fuel cell anode was monitored with the same setup described above. Solutions of potassium hydroxide $(\mathrm{KOH})$ at different concentrations were added as fuel cell electrolyte. Fuel cell voltage/current was recorded using a DropSens $\mu$ Stat 400 Bipotentiostat/Galvanostat and DropView 8400 Software (DropSens S.L., Asturias, Spain).

\section{$\mathrm{KOH}$ pad characterization.}

The electrolyte pads were prepared by drying a concentrated solution of $\mathrm{KOH}$ onto cellulose strips. The $\mathrm{KOH}$ solutions were prepared at concentrations between $3 \mathrm{M}$ and $10 \mathrm{M}$. The dispensed volumes of $\mathrm{KOH}$ solution that were tested ranged between 5 to $60 \mu \mathrm{L}$ per pad. The combination of $\mathrm{KOH}$ concentration and dispensed volume gave the actual amount of $\mathrm{KOH}$ contained in the dried pad. Two cellulose materials were evaluated, CF3 and CF10 (GE Healthcare).

Two drying methods were tested, using either a lyophilizer or a desiccator. In the first method, the pads impregnated with $\mathrm{KOH}$ solution were frozen in liquid nitrogen, then placed inside dedicated canisters in a lyophilizer (FreeZone 2.5, Labconco, Kansas City, MO, USA), which sublimated the water from the $\mathrm{KOH}$ solution contained in the pad. In the second method, the pads were placed over a hydrophobic supporting grid inside a plastic desiccator containing an anhydrous calcium sulfate desiccant (Drierite, W.A. Hammond Drierite Co., Xenia, $\mathrm{OH}$ ), after addition of $\mathrm{KOH}$ solution and let dry for at least $24 \mathrm{~h}$ before use.

Two arrangements of electrolyte pad and fuel cell strip were evaluated, namely series and parallel configurations (Figure S6). In the parallel configuration, the $\mathrm{KOH}$ pad is placed over a single continuous fuel cell strip whereas in the series configuration the $\mathrm{KOH}$ pad connects the two parts of a segmented fuel cell strip.

A solution of $0.2 \mathrm{wt} \%$ Indigo Carmine $\mathrm{pH}$ indicator (Sigma-Aldrich, St. Louis, Missouri, USA) was used to evaluate the release of $\mathrm{KOH}$ into the fuel cell strip. This $\mathrm{pH}$ indicator shows a dark blue color at $\mathrm{pH}<12$ and shifts to yellow at $\mathrm{pH}>14$ (corresponding to a $\mathrm{KOH}$ concentration of $1 \mathrm{M}$ or above). The pads were mounted on similar laminates than those used for the fuel cell but without including the electrodes.

\section{Results and Discussion}

The development of the paper-based hydrogen fuel cell was performed in three stages. First, the fuel cell performance was characterized at different hydrogen flow rates, electrolyte concentrations and temperatures. Secondly, the hydrogen generator was characterized and optimized to deliver a suitable hydrogen flow rate and temperature rise upon the addition of different liquid samples. Finally, the power performance of the full device was characterized combining the best performing conditions of hydrogen generator and fuel cell.

\subsection{Paper-based hydrogen fuel cell}

To evaluate its electrochemical performance, the paper-based fuel cell was characterized under controlled electrolyte concentrations, temperatures and hydrogen flow rates. After this 
characterization, the electrolyte was dried in a cellulose pad to be released into the fuel cell upon the addition of the liquid sample. The electrolyte pad drying, rehydration and release was optimized to deliver a concentration between the fuel cell electrodes within the range of best operation.

\subsubsection{Effect of $\mathrm{KOH}$ concentration and $\mathrm{H}_{2}$ flow rate in fuel cell performance}

The paper-based fuel cell performance was evaluated at room temperature under electrolyte concentrations of $0.5 \mathrm{M}, 1 \mathrm{M}, 2 \mathrm{M}, 3 \mathrm{M}$ and $5 \mathrm{M} \mathrm{KOH}$ and $\mathrm{H}_{2}$ flow rates of $0.1,0.5,1,2,3$ and $5 \mathrm{~mL}$ $\mathrm{min}^{-1}$. Open circuit voltage (OCV) measurements and polarization curves from several identical fuel cells were recorded at least 3 times under each condition. Figure S1 shows the OCV values at every tested condition. The characterization shows OCVs from $0.90 \mathrm{~V}$ to $1.04 \mathrm{~V}$, with lower values corresponding to higher $\mathrm{KOH}$ concentrations and low $\mathrm{H}_{2}$ flow rates, whereas higher OCV values are recorded with lower $\mathrm{KOH}$ concentration and high $\mathrm{H}_{2}$ flow rates. The maximum output power was calculated from the polarization curves and plotted in Figure 2a. As can be seen, for all the tested electrolyte concentrations there is a quasi-linear increase in power density as the hydrogen flow rate increases from 0.1 to $1 \mathrm{~mL} \mathrm{~min}^{-1}$. The power still shows a significant increase until $2 \mathrm{~mL} \mathrm{~min}^{-1}$, when it reaches the maximum fuel cell performance. Higher hydrogen flow rates show only marginal improvements in maximum output power.

Regarding the effect of electrolyte concentration on fuel cell performance, the paper-based fuel cell follows a behavior previously observed in hydrogen fuel cells[43], i.e. the optimal fuel cell performance is found at a certain range of $\mathrm{KOH}$ concentrations (see inset from Figure 2a). In our case, the output power increases when $\mathrm{KOH}$ is increased from $0.5 \mathrm{M}$ to $1 \mathrm{M}$, achieving an optimal fuel cell performance with a $\mathrm{KOH}$ concentration between $1 \mathrm{M}$ and $2 \mathrm{M}$, with a remarkable maximum output power of $26.8 \mathrm{~mW}$. This power delivery is $1-3$ orders of magnitude higher that other reported paper-based fuel cells. As has been demonstrated by others, higher $\mathrm{KOH}$ concentrations lead to reduced fuel cell performance due to increased solution viscosity (affecting mass transport processes) and competitive hydroxyl absorption to anode surface.[43]
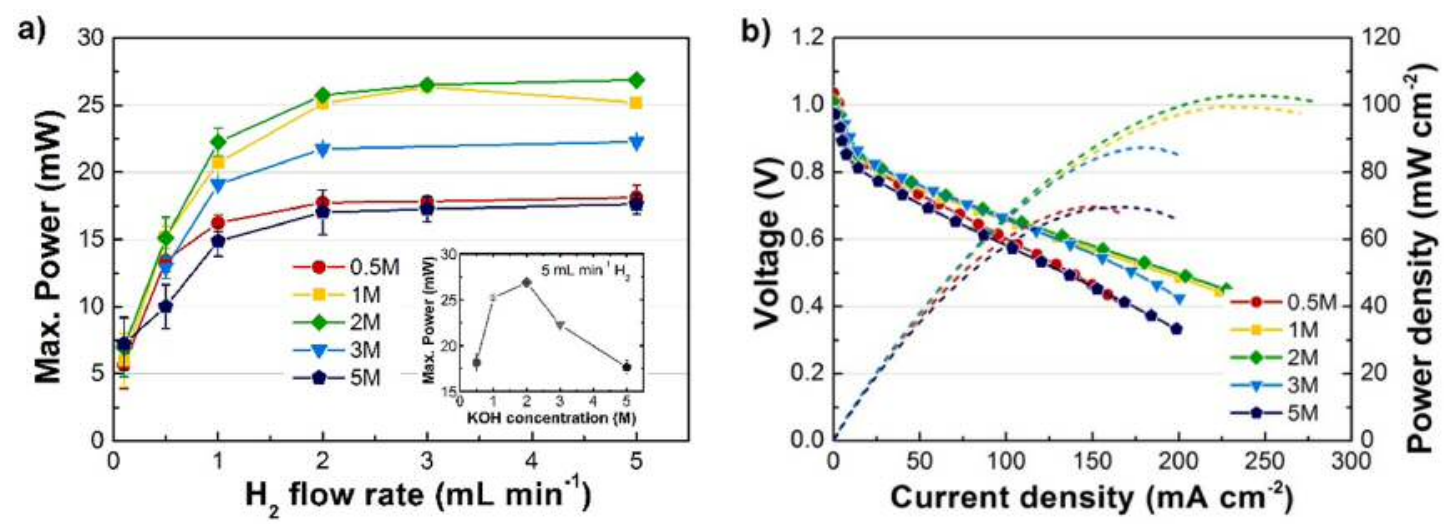

Figure 2. a) Maximum power obtained from polarization curves of fuel cells with different $\mathrm{KOH}$ concentrations and hydrogen flow rates. Inset shows the maximum power at a $\mathrm{H}_{2}$ flow rate of $5 \mathrm{~mL} \mathrm{~min}^{-1}$. Plotted are data means and standard deviation, $\mathrm{n}=3$. b) Polarization curves of fuel cell working at different $\mathrm{KOH}$ concentrations at room temperature and a $\mathrm{H}_{2}$ flow rate of 2 $\mathrm{mL} \mathrm{min}^{-1}$.

Figure $2 \mathrm{~b}$ presents the polarization curves for the fuel cell working at $2 \mathrm{~mL} \mathrm{~min}^{-1}$ showing the effect of $\mathrm{KOH}$ concentration on the performance. Current and power have been normalized to the projected geometric active electrode area of $0.25 \mathrm{~cm}^{2}$. The peak power of the fuel cell working with $0.5 \mathrm{M} \mathrm{KOH}$ is $71.0 \pm 1.2 \mathrm{~mW} \mathrm{~cm}^{-2}$, it increases to $100.5 \pm 0.7$ and $103.0 \pm 0.1 \mathrm{~mW} \mathrm{~cm}^{-2}$ with $1 \mathrm{M}$ and $2 \mathrm{M} \mathrm{KOH}$ respectively. After this point the power decreases to $87.3 \pm 1.1 \mathrm{~mW} \mathrm{~cm}^{-2}$ with $3 \mathrm{M} \mathrm{KOH}$ and $68.0 \pm 6.6 \mathrm{~mW} \mathrm{~cm}^{-2}$ with $5 \mathrm{M} \mathrm{KOH}$. The power densities achieved by this paper-based hydrogen fuel cell are at least one order of magnitude higher than any reported paper-based fuel cell up to date. Furthermore, this performance corresponds to the typical values reported for state-of-the-art 
hydrogen fuel cell systems working at room temperature with more complex and expensive ancillary devices.[43, 44]

\subsubsection{Effect of temperature on fuel cell performance}

It is known that temperature has a complex effect on fuel cell performance. On the one hand, the kinetics of chemical reactions increases with temperature because the probability of collisions between molecules is higher. Also, increasing temperature improves ion conductivity and mass transport. On the other hand, according to Nernst equation increasing temperature results in lower cell voltages (ca. $23 \mathrm{mV}$ per $100^{\circ} \mathrm{C} \mathrm{H}_{2}-\mathrm{O}_{2}$ fuel cell), so that net fuel cell efficiency could be lower. For this reason, the paper-based fuel cell was characterized at a temperature of $35^{\circ} \mathrm{C}$, which is a temperature that can be reached by the hydrogen generator that will be presented in the next section. The performance of the fuel cell was characterized with an electrolyte concentration of $1 \mathrm{M}$ $\mathrm{KOH}$ and a hydrogen flow rate of $1 \mathrm{~mL} \mathrm{~min}{ }^{-1}$, measuring polarization curves and the continuous operation under a fixed load. The results, shown in Figure 3, are compared against the response at room temperature $\left(22.0 \pm 1^{\circ} \mathrm{C}\right)$. The polarization curves show an average increase of $16 \%$ in peak power when temperature is raised to $35^{\circ} \mathrm{C}$, going from 20.4 to $23.6 \mathrm{~mW}$.

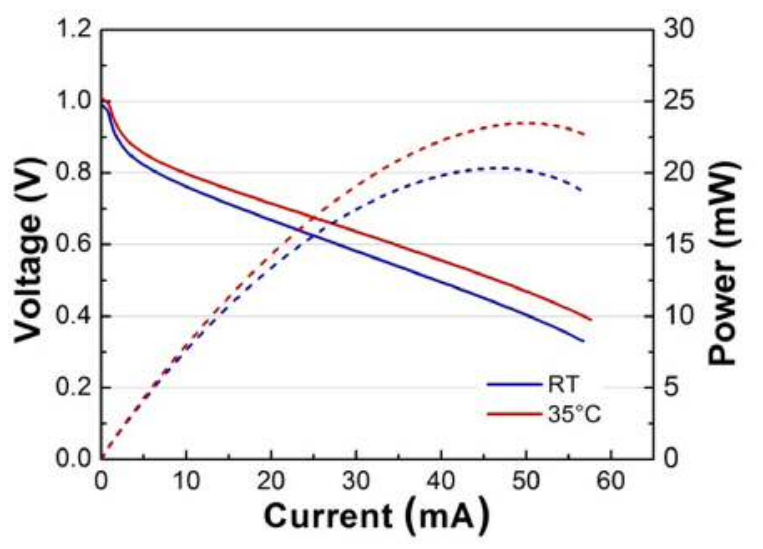

Figure 3. Polarization curves of paper-based fuel cell at room temperature $\left(22.0 \pm 1{ }^{\circ} \mathrm{C}\right)$ and $35^{\circ} \mathrm{C}$ working with a steady hydrogen flow rate of $1 \mathrm{~mL} \mathrm{~min}{ }^{-1}$ and $1 \mathrm{M} \mathrm{KOH}$ electrolyte concentration.

\subsubsection{Electrolyte pad optimization}

In order to simplify the user operation and eliminate the need to supply a liquid electrolyte to the fuel cell, a cellulose pad containing dry electrolyte was developed. Such pads are used to deliver reagents in simple lateral flow diagnostic devices. They greatly simplify storage of biological reagents, at the cost of producing a time-varying concentration of the reagent delivered. Here, the pad was placed in contact with the fuel cell paper strip so the electrolyte is rehydrated and released into the stream upon the addition of water or a saline solution at the device inlet pad. In order to obtain an electrolyte concentration at the fuel cell electrodes that falls within the optimal values, several parameters were optimized, such as pad material and dimensions, $\mathrm{KOH}$ concentration and volume, arrangement of pad with respect to the strip, as well as the drying method (using either a lyophilizer or a desiccator).

Both $\mathrm{KOH}$ pad drying methods resulted in pads with satisfactory $\mathrm{KOH}$ release into the fuel cell strip. Since the lyophilized pads didn't show a significant advantage, the desiccator method was preferred because it is considerably simpler and easier to setup. It was observed that the cellulose pads shrink about $20 \%$ after drying; therefore the cut size of the initial pads was adjusted to obtain a final 
pad with dimensions of $5 \times 15 \mathrm{~mm}$. Furthermore, the relation between the size of the initial cellulose pad and the dispensed volume of $\mathrm{KOH}$ solution should be taken into account, i.e. the pad should be fully impregnated by the solution to avoid inhomogeneous shrinkage during drying.

The pads were first characterized using a solution of $\mathrm{pH}$ indicator to visually evaluate the release and distribution of $\mathrm{KOH}$ into the fuel cell strip. Then, the most suitable pad configurations were tested with the fuel cell electrodes measuring polarization curves and continuous operation. For the first characterization, indigo carmine solution was added to the strips and the change in color was recorded with a webcam for an hour. A video of one of these experiments can be found as Electronic Supplementary Information (Video S1). Figure S2 shows an example of the $\mathrm{KOH}$ tests strips before and after addition of $\mathrm{pH}$ indicator solution. The supplied solution has a pH under 12 (blue) that changes to 14 or above (yellow) after passing through the $\mathrm{KOH}$ pad.

After this characterization, the series configuration showed longer rehydration times, the formation of a fluid front with a very high $\mathrm{KOH}$ concentration, and channeling of liquid around the pad. All this led to a higher variability on the $\mathrm{KOH}$ concentration at the fuel cell electrode region. In contrast, it was observed that the paralle/ configuration results in a faster, more steady and reproducible release of $\mathrm{KOH}$ into the fuel cell strip. In most of the cases the release of $\mathrm{KOH}$ was highly efficient, therefore the pads containing the highest amounts of $\mathrm{KOH}$ yielded concentrations in the strip above $2 \mathrm{M}$, which is detrimental to the fuel cell performance as shown in the previous section.

Taking into account all the previous factors, it was determined that the optimal $\mathrm{KOH}$ pad consisted of CF3 cellulose cut with initial dimensions of $6 \times 17.25 \mathrm{~mm}$ and loaded with $45 \mu \mathrm{L}$ of a $5 \mathrm{M} \mathrm{KOH}$ solution. The operation of this $\mathrm{KOH}$ pad was then tested in the paper-based fuel cell. First, the polarization curves of the fuel cells were measured under the same $\mathrm{H}_{2}$ flow rate used previously, within the range of $0.5-5 \mathrm{~mL} \mathrm{~min}{ }^{-1}$. Figure $4 a$ shows the average maximum power output of the fuel cells extracted from the polarization curves. It can be seen that a maximum power output of $24.9 \mathrm{~mW}$ is obtained with flow rates above $2 \mathrm{~mL} \mathrm{~min}^{-1}$. These results are compared with the maximum power values obtained with $\mathrm{KOH}$ concentrations, showing that the fuel cell with the $\mathrm{KOH}$ pad yields values within the optimal concentration range of 1-3 $\mathrm{M} \mathrm{KOH}$.

The previous characterization allowed determination that a load of $20 \Omega$ corresponded to a fuel cell operation point near its maximum output power. The continuous operation of the fuel cell working under this load was then recorded over one hour. Figure $4 \mathrm{~b}$ shows the output voltage and power under a fixed $20 \Omega$ load with a $\mathrm{H}_{2}$ flow rate of $1 \mathrm{~mL} \mathrm{~min}^{-1}$. In this case, the power reaches a value around $16.8 \mathrm{~mW}$ that remains stable for up to $25 \mathrm{~min}$. After this time, the power slowly decreases to $12.7 \mathrm{~mW}$ at the end of one hour, probably due to water flooding at the anode porous electrode.
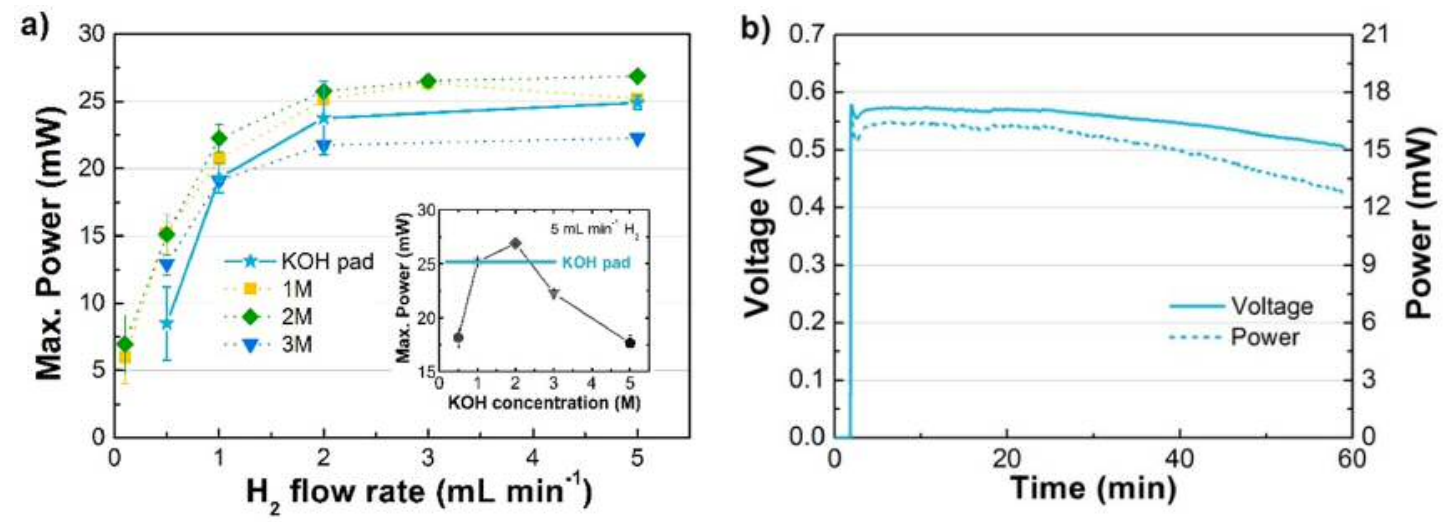

Figure 4. a) Maximum power obtained from polarization curves of fuel cell with $\mathrm{KOH}$ pad at different hydrogen flow rates. Inset shows the comparison of the maximum power at a $\mathrm{H}_{2}$ flow rate of $5 \mathrm{~mL} \mathrm{~min}^{-1}$. Data points represent mean values, error bars represent \pm one standard deviation, for $n \geq 3$. b) Fuel cell output voltage and power under a $20 \Omega$ load with a $\mathrm{H}_{2}$ flow rate of $1 \mathrm{~mL} \mathrm{~min}^{-1}$ after supplying water in the inlet pad. 


\subsection{Capillary-based hydrogen generator}

The custom-build hydrogen generator was characterized under conditions suitable for the correct operation of the paper-based hydrogen fuel cell. Previous studies of chemical heaters using the $\mathrm{MgFe}$ reaction have highlighted parameters which affect the heat production.[39] Here we evaluate the effect of two of the most influential variables in both heat and hydrogen production, i.e. the amount of $\mathrm{NaCl}$ as electrolyte (both stored in solid form and supplied in solution) and the amount of $\mathrm{MgFe}$ stored in the device.

\subsubsection{Effect of $\mathrm{NaCl}$ content}

The concentration of sodium chloride is one of the factors that determines the MgFe reaction rate in chemical heaters. Even though the present device is intended to work with physiological solutions (typically around a saline concentration of $0.9 \mathrm{wt} \%$ or $150 \mathrm{mM} \mathrm{NaCl}$ ), a wider range of salt concentrations was tested to evaluate the influence on the hydrogen generation and temperature of the device. The hydrogen generator was characterized with water and $\mathrm{NaCl}$ concentrations of $0.9,3$ and $9 \mathrm{wt} \% \mathrm{NaCl}$. Also, different amounts of salt were dry-stored in the cellulose strip $(0,6,12$ and $20 \mathrm{mg} \mathrm{NaCl}$ ) to be diluted by the liquid sample supplied in the device. This would ensure a minimum saline concentration reaching the reaction chamber independently of the concentration in the supplied sample. Figure 5a shows a summary of the tested conditions. Figure S3 shows the setup that was used to calculate the hydrogen flow rate produced by the hydrogen generator and Video S2 presents the recording of one of these tests.

The combination of water and no salt stored in the strip was not tested as it results in a very limited $\mathrm{MgFe}$ reaction rate. An excess of salt concentration (above $9 \mathrm{wt} \%$ in solution or $20 \mathrm{mg}$ in strip) resulted in device failure or hydrogen leakage. The rest of the conditions shown in Figure 5a were successfully characterized. These tested concentrations are relevant to evaluate the response of the device supplied by deionized water, a typical physiological concentration $(0.9 \mathrm{wt} \%)$ and the salt concentration found in seawater ( $3 \mathrm{wt} \%)$.

As seen in Figure $5 b$, the temperature in the $\mathrm{H}_{2}$ generator shows a sudden increase as the $\mathrm{NaCl}$ solution triggers the $\mathrm{MgFe}$ reaction. As the $\mathrm{MgFe}$ is depleted, the temperature decreases at a rate determined by heat transfer properties of the system. This temperature profile agrees with observations in previous chemical heaters studies using this reaction.[37-39] The average peak temperature for all tested combinations is $30.0 \pm 2.8^{\circ} \mathrm{C}$. Higher $\mathrm{NaCl}$ concentrations result in higher peak temperatures. In this case, the highest average temperatures is achieved with solution of 3 $w t \% \mathrm{NaCl}$ (average $31.7^{\circ} \mathrm{C}$ ), however this condition has the highest variability, with a standard deviation of $3.3^{\circ} \mathrm{C}$. The results with $0.9 \%$ wt show the smallest variability $\left(1.2^{\circ} \mathrm{C}\right)$ considering all the tested conditions.

Figure $5 \mathrm{~b}$ also shows the hydrogen flow rate produced by the hydrogen generator at the measured saline conditions (colored symbols represent average values ( $n=3$ minimum) calculated from the recorded videos). As is found for the temperature profile, the hydrogen flow rate profile shows an initial peak due to the fact that the largest surface of the magnesium particles is exposed to a fresh $\mathrm{NaCl}$ solution as the bed of $\mathrm{MgFe}$ is first wetted. The hydrogen production rate decreases as the $\mathrm{MgFe}$ is depleted and by-products hinder electrolyte access to unreacted $\mathrm{Mg}$ (Equation 1). It can be seen from Figure $5 \mathrm{~b}$ that $\mathrm{NaCl}$ in solution has a higher impact on hydrogen production than $\mathrm{NaCl}$ stored in the cellulose strip. The lowest hydrogen flow rates are developed when the device is supplied with deionized water (up to $1 \mathrm{~mL} \mathrm{~min}^{-1}$ ) whereas the highest flow rates are achieved with 3 
wt $\% \mathrm{NaCl}$ solution (up to $3 \mathrm{~mL} \mathrm{~min}^{-1}$ ). When the device is supplied with $0.9 \mathrm{wt} \% \mathrm{NaCl}$, the hydrogen flow rates show intermediate values (up to $2 \mathrm{~mL} \mathrm{~min}^{-1}$ ) that are sustained for longer times.
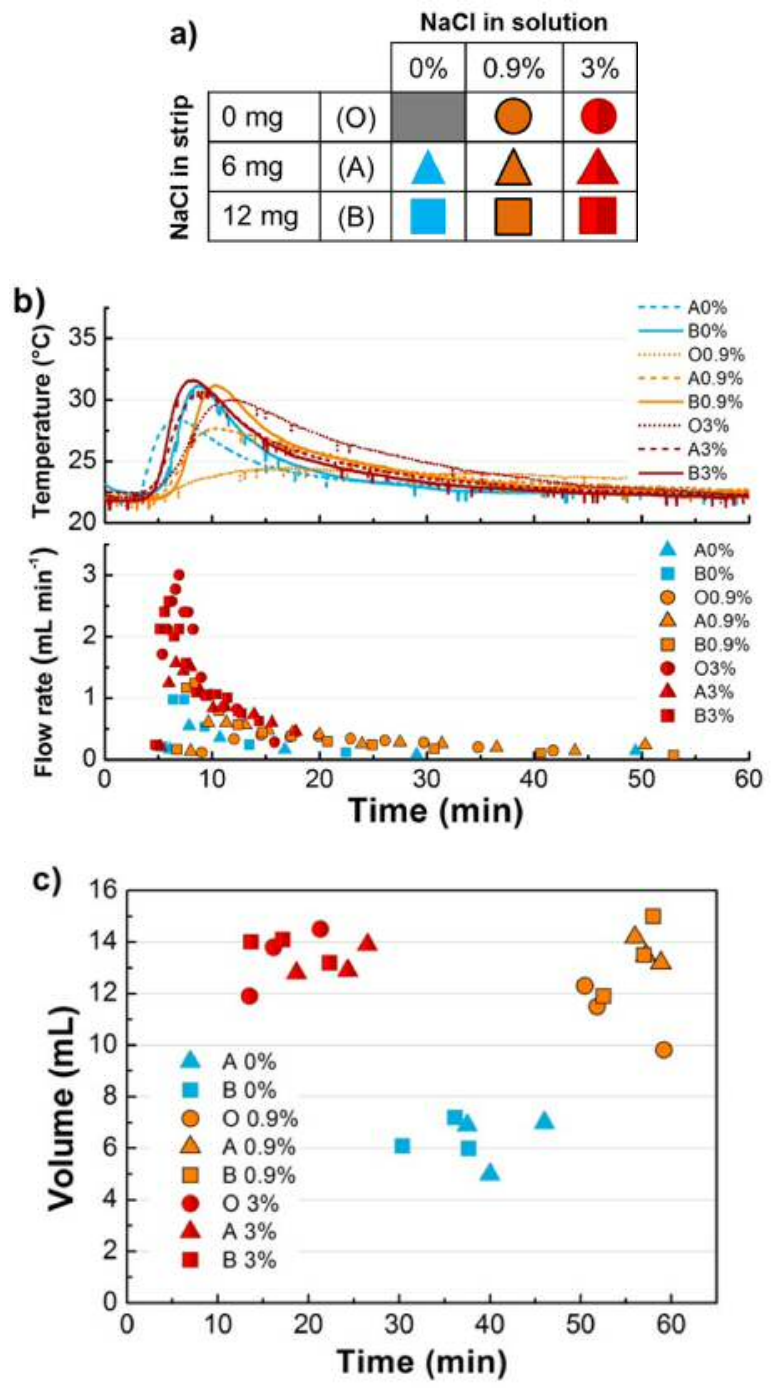

Figure 5. a) Summary of $\mathrm{NaCl}$ conditions tested on hydrogen generator. b) Hydrogen flow rates (symbols) and temperatures (lines) produced by the hydrogen generator under different saline concentrations. Data points represent means of at least $\mathrm{n}=3$. c) Maximum volumes of hydrogen produced by the hydrogen generator under different saline concentrations.

This experiment also measured the total volume of hydrogen produced at each $\mathrm{H}_{2}$ generator and consequently, the conversion of $\mathrm{MgFe}$ alloy to hydrogen gas. In order to calculate the conversion efficiency of the devices, we first measured the average hydrogen production from the specific $\mathrm{MgFe}$ alloy that was used in this study. It was found that the average conversion ratio is $0.91 \pm 0.02$ $\mathrm{mL}$ of $\mathrm{H}_{2}$ per $\mathrm{mg}$ of $\mathrm{MgFe}$ at standard ambient conditions. Figure $5 \mathrm{c}$ shows the maximum volume of hydrogen produced by the tested devices and the time in which the production ceased. The total $\mathrm{H}_{2}$ volume produced by the hydrogen generators working with both tested $\mathrm{NaCl}$ concentrations is very similar, $12.8 \mathrm{~mL}$ with $0.9 \mathrm{wt} \% \mathrm{NaCl}$ and $13.5 \mathrm{~mL}$ with $3 \mathrm{wt} \% \mathrm{NaCl}$, corresponding to $56.1 \%$ and $59.2 \%$ conversion rates respectively. When the generator is supplied with deionized water, the total amount of hydrogen produced is considerably lower, with an average of $6.4 \mathrm{~mL}$ that corresponds to a $28 \%$ conversion of $\mathrm{MgFe}$ to $\mathrm{H}_{2}$. 
Based on this characterization it was determined that the hydrogen generator supplied with $0.9 \mathrm{wt} \%$ $\mathrm{NaCl}$ yielded the best performance, as it results in a high $\mathrm{Mg}-\mathrm{to}-\mathrm{H}_{2}$ conversion with hydrogen flow rates sustained for longer times.

\subsubsection{Effect of MgFe mass}

The amount of MgFe alloy in the reaction chamber of the hydrogen generator was increased from $25 \mathrm{mg}$ to $50 \mathrm{mg}$ to evaluate the effect on the hydrogen flow rate and temperature. The generators were tested using cellulose strips with $6 \mathrm{mg} \mathrm{NaCl}$ and activated by water, $0.9 \mathrm{wt} \% \mathrm{NaCl}$ and $3 \mathrm{wt} \%$ $\mathrm{NaCl}$ solutions. The hydrogen flow rates over time are shown in Figure 6a. The increase of $\mathrm{MgFe}$ alloy results in a substantial increase on the hydrogen flow rate, reaching values as high as $6 \mathrm{~mL}$ $\min ^{-1}$ during the first 5 minutes when supplied with $3 \mathrm{wt} \% \mathrm{NaCl}$ solution. When the devices are supplied with $0.9 \mathrm{wt} \% \mathrm{NaCl}$, the average maximum hydrogen flow rate is $2.25 \mathrm{~mL} \mathrm{~min}^{-1}$, which decays slowly during one hour. The reactors are able to sustain a production around $1 \mathrm{~mL} \mathrm{~min}{ }^{-1}$ for 20 minutes when supplied with either $\mathrm{NaCl}$ solution. As shown in Figure $6 \mathrm{a}$, the temperature in the reaction chamber shows an increase of up to $13^{\circ} \mathrm{C}$, reaching a maximum temperature of $35.5^{\circ} \mathrm{C}$ when supplied with $3 \mathrm{wt} \% \mathrm{NaCl}$. The temperature peaks using water and $0.9 \mathrm{wt} \% \mathrm{NaCl}$ are both very similar, reaching $32.3^{\circ} \mathrm{C}$ and $32.6^{\circ} \mathrm{C}$ respectively.

The average maximum volumes of hydrogen produced with $50 \mathrm{mg}$ of $\mathrm{MgFe}$ show also an increase when compared with the reactors containing $25 \mathrm{mg}$ of MgFe. The measured values, shown in Figure $6 \mathrm{~b}$, are 10,33 and $37.5 \mathrm{~mL}$ for water, $0.9 \mathrm{wt} \%$ and $3 \mathrm{wt} \% \mathrm{NaCl}$ respectively. This characterization shows that increasing the content of MgFe stored in the device results in higher flow rates and temperatures and also confirms that suppling a $0.9 \mathrm{wt} \% \mathrm{NaCl}$ solution yields hydrogen flow rates suitable for the fuel cell during longer times.
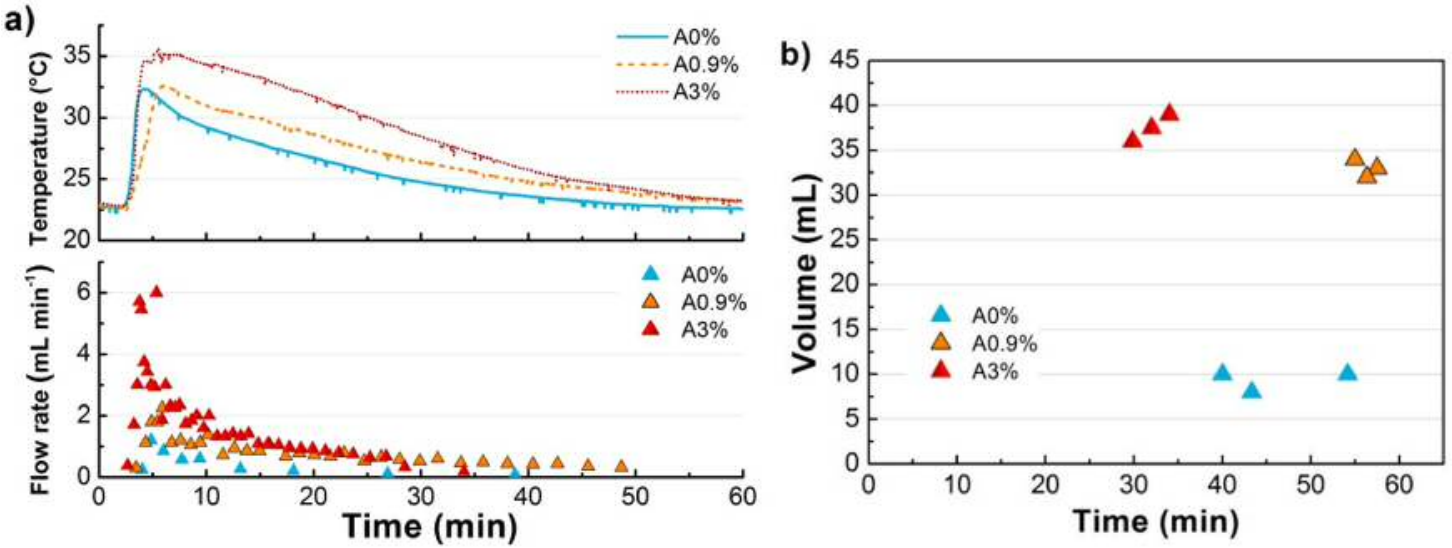

Figure 6. a) Hydrogen flow rate (symbols) and temperatures (lines) produced by reactor containing $50 \mathrm{mg} \mathrm{MgFe} \mathrm{under}$ different saline concentrations. Data points and lines represent mean values, $n=3$. b) Maximum volumes of hydrogen produced by the hydrogen generator.

\subsection{Integration of hydrogen fuel cell strip}

The characterization of the paper fuel cell and the $\mathrm{H}_{2}$ generator module allowed determination of a set of parameters yielding the best performance. To enable activation of both modules with the same liquid sample, $\mathrm{KOH}$ and $\mathrm{NaCl}$ were stored in different cellulose pads so an optimal electrolyte concentration could be released upon the addition of water at the common entrance. However, it was seen that $\mathrm{MgFe}$ yielded the best $\mathrm{H}_{2}$ generation rate when, in addition of integrating a pad containing $6 \mathrm{mg}$ of $\mathrm{NaCl}$, the liquid sample supplied to activate the reaction contained $0.9 \mathrm{wt} \%$ of $\mathrm{NaCl}$. This concentration corresponds to the salt concentration of normal saline. In order to see if the fuel cell performance was affected when activated with a fluid containing $0.9 \mathrm{wt} \% \mathrm{NaCl}$, it is 
tested at different $\mathrm{H}_{2}$ rates. Figure $\mathrm{S} 4$ shows that no difference is observed in the maximum power density meaning that the $\mathrm{NaCl}$ do not affect significantly the dilution rate of the $\mathrm{KOH}$ pad or the conductivity of the electrolyte.

The complete fuel cell/ $/ \mathrm{H}_{2}$ generator system assembled with optimized parameters has dimensions of $6.0 \mathrm{~cm} \times 0.9 \mathrm{~cm} \times 0.3 \mathrm{~cm}$, which is similar to the form factor of commercial lateral flow tests. Figure 7 shows pictures of the final device that integrated an $\mathrm{H}_{2}$ reactor containing $6 \mathrm{mg} \mathrm{NaCl}$ stored in the $\mathrm{H}_{2}$ generator strip, $50 \mathrm{mg}$ of MgFe alloy and a fuel cell with $\mathrm{KOH}$ pad made from $45 \mu \mathrm{L}$ of $5 \mathrm{M} \mathrm{KOH}$
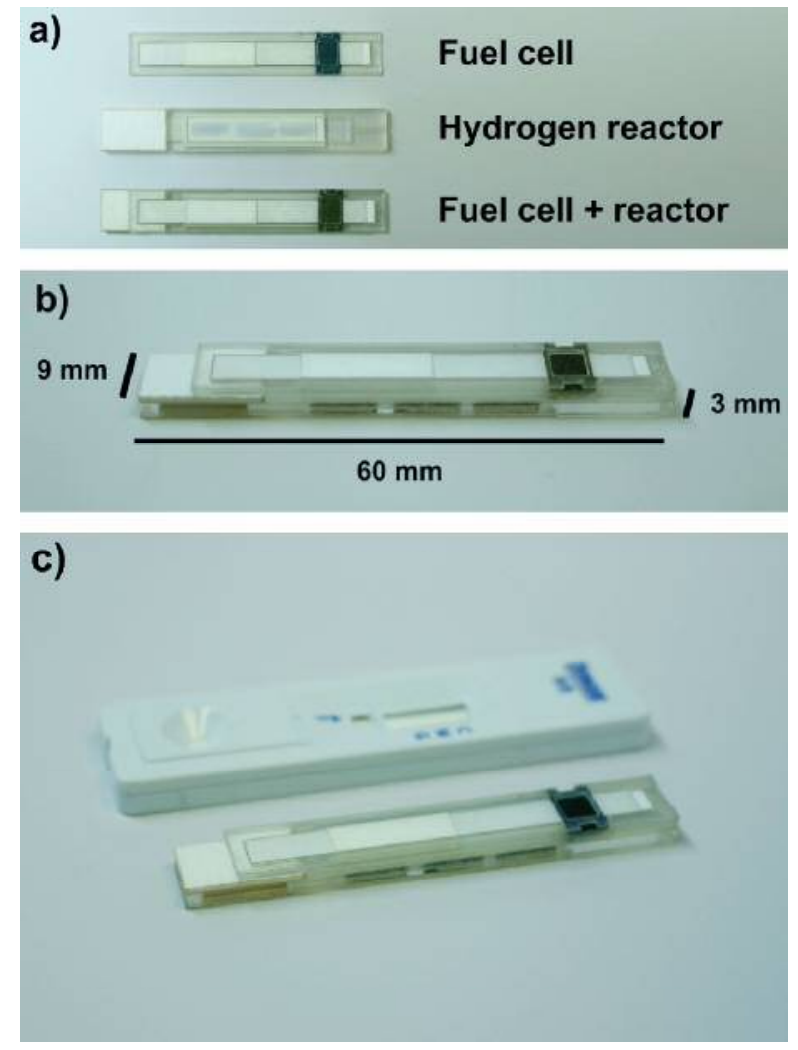

Figure 7. a) Top view photo of fuel cell, hydrogen reactor and integrated device. b) Isometric view of the final device with dimensions. c) Paper-based hydrogen fuel cell (foreground) compared to a typical lateral flow test (background).

The device performance was tested adding a $0.9 \mathrm{wt} \% \mathrm{NaCl}$ solution and was characterized by measuring polarization curves continuously over one hour. In each test, the device was activated by adding $500 \mu \mathrm{L}$ of liquid sample to the inlet pad 20 seconds after the start of the measurement. Figure S5 shows polarization curves obtained at different times after activation. The device provides a maximum power around $25 \mathrm{~mW}$ for more than 6 minutes and then decreases steadily until it ceases to function after 60 minutes of operation. Figure 8 depicts the maximum power values obtained from all the measured polarization curves. The profile of the delivered power matches the hydrogen flow rate profiles measured from the hydrogen generator (shown in Figure 6a).

The power output of the device working under a fixed load of $20 \Omega$ was also evaluated. Figure S5 shows that this load sets the device to work at an operating point around $70 \%$ of its maximum performance. The fuel cell reaches an output power of up to $18.6 \mathrm{~mW}$ during the first 5 minutes after activation and then decreases slowly until it drops to $1 \mathrm{~mW}$ after an hour. In order to evaluate the sufficiency of the electric energy generated by the present device, Figure 8 includes the power consumption over time of two commercial electronic tests: a glucometer and a digital pregnancy 
test. It can be seen that the power source presented here can cover the energy needs of both tests. For comparison, the power delivered by two different kind of commercial batteries is also included, i.e. a CR1616 coin cell[45] like the one used to power digital pregnancy tests, and a 110-ST1 printed battery from Blue Spark[46] also proposed for portable single-use applications. More detailed information on their power performance specifications are included in Table S1. Assuming these batteries provide a steady voltage output, it can be seen that the coin cell also fulfills the power needs of the digital tests whereas the printed battery might be unable to provide enough power to run the periods of high demand.

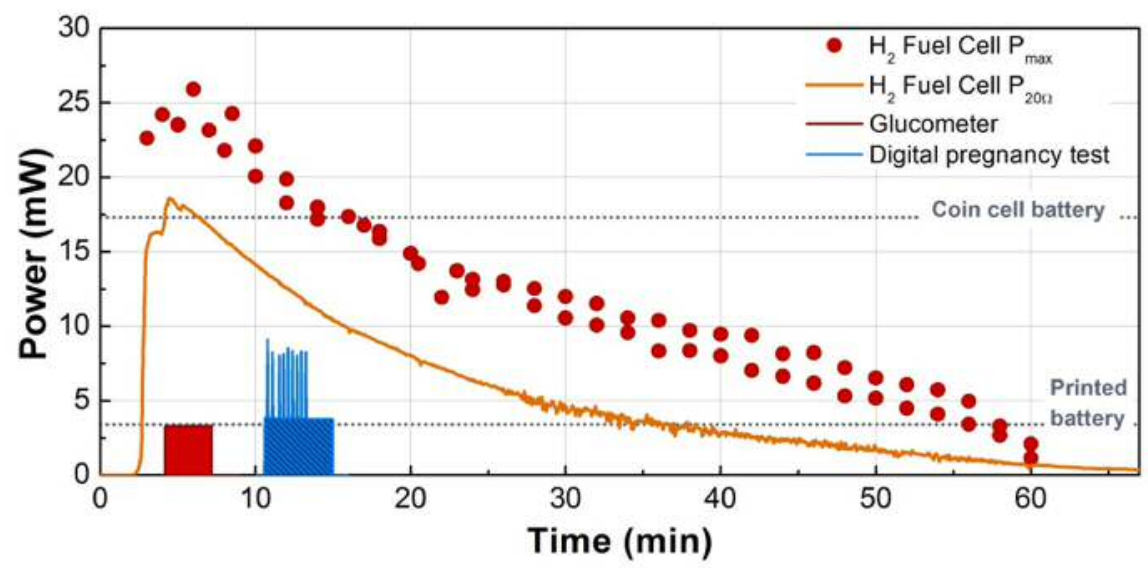

Figure 8. Performance of paper-based hydrogen fuel cell. Data points represent maximum power calculated from continuous polarization curves. The orange line represents sustained fuel cell power output under a load of $20 \Omega$. Areas represent the power consumption of common point-of-care diagnostics devices (glucometer, digital pregnancy test). Dotted lines represent calculated power of two commercial batteries.

The results show a successful integration of a paper-based fuel cell and an exothermic hydrogen generator in a compact design. The output power delivered by this device yields a maximum power density of $4.8 \mathrm{~mW} \mathrm{~cm}^{-2}$ (normalized to the total device footprint of $5.4 \mathrm{~cm}^{2}$ ) which is comparable to the power of coin cell batteries $\left(8.7 \mathrm{~mW} \mathrm{~cm}^{-2}\right)$ currently used in disposable digital pregnancy and other portable appliances. Table S1 includes the total net power and power density per device footprint for relevant paper-based fuel cells found in the literature. This direct comparison facilitates to quantify the advantages in power delivery of the paper-based hydrogen fuel cell over previously reported approaches. As it can be seen, all of reported fuel cells use liquid (or dissolved) fuels. The main difference of the fuel cell here presented is that this is the only one that operates with a gaseous fuel. The use of hydrogen prevents slow oxidation reactions kinetics, electrode poisoning (e.g. due to partial oxidation of alcohols) and crossover. All these effects hinder the power provided by fuel cells using alcohols or other more complex hydrocarbon molecules.

This hydrogen fuel cell was designed in a familiar size and form factor but it can easily be customized to meet the power demands of a particular application. The output power normalized to the active geometrical electrode area $\left(0.25 \mathrm{~cm}^{2}\right)$ yields a maximum net power density of $103.2 \mathrm{~mW}$ $\mathrm{cm}^{-2}$, which is comparable to that delivered by more sophisticated hydrogen fuel cells. The faradaic efficiency of the fuel cell was $14.4 \%$, which was calculated comparing the theoretical charge contained in the mass of $\mathrm{Mg}$ stored in the device and the actual electric charge measured from the device when working at maximum power. Some of the factors affecting the efficiency of the system are the incomplete conversion of MgFe into $\mathrm{H}_{2}$, the amount of $\mathrm{H}_{2}$ released unreacted to atmosphere and the inherent ohmic losses of the device. This result shows that there is still much room for device optimization beyond the performance of this proof-of-concept. 
The power output duration and profile directly depend on the MgFe reaction rate producing the hydrogen flow rate and temperature rise. Besides the conditions characterized in this study, the system can be further optimized by adjusting other parameters such as MgFe particle size, Mg ratio in the $\mathrm{MgFe}$ alloy or the $\mathrm{NaCl}$ solution delivery rate.

The shelf life of the integrated fuel cell is expected to comply with that of the devices to be powered. Conveniently, the storage requirements for the magnesium-iron alloy, currently widely used for portable meals, are already less stringent than the storage requirements of the portable bioassays they could potentially provide hydrogen to power. The bioassay reagents and exothermic reactants should both be stored in a water-tight container with desiccant for storage and transport, which are the right conditions for the fuel cell to be ready for use when needed.

Cost effectiveness is one of the biggest concerns when trying to deploy point-of-care diagnostics in the field. Therefore, minimizing the cost of the devices is currently the biggest challenge. In this respect, the $\mathrm{Pt}$ content in the fuel cell electrodes represents the most expensive component of the device (1 $\mathrm{mg} \mathrm{cm}^{-2} \mathrm{Pt} \times 0.5 \mathrm{~cm}^{2} \times 0.254 \$ / \mathrm{mg} \mathrm{Pt}=\$ 0.127$ per fuel cell).[47] This issue is currently being addressed by many groups working in the fuel cell field. The most developed strategies include increasing the mass activity of the Pt particles[48] or the use of bimetallic alloys.[49] Furthermore, state-of-the-art strategies eliminate noble metals altogether by the use of alternative low cost materials based on transition metals such as Fe or Co,[50-53] material morphologies with a highly catalytic active surface,[54] or hydrogenase-based enzymatic catalysts.[55] It is expected that these strategies will provide effective solutions to reduce the electrode cost.

The presented paper-based hydrogen fuel cell was designed as a stand-alone power source that produces its own hydrogen from a dry-stored compound. Nevertheless, current work is now focused on the integration of this fuel cell into portable diagnostic devices utilizing the heating $\mathrm{MgFe}$ reaction while harvesting waste hydrogen produced during operation for conversion to electricity for powering additional functionalities. The duration of the power delivery can be extended as these devices use up to $20 \mathrm{x}$ more $\mathrm{MgFe}$ for a single test (and consequently, produce as much hydrogen) than the amount used in the fuel cells presented here.[39-42] This approach implies reusability of the fuel cells for more than one measurement, thus reducing the overall cost per test.

\section{Conclusions}

This work demonstrates a stand-alone power source that integrates a paper-based hydrogen fuel cell with a customized chemical heater that produces hydrogen in-situ upon the addition of a liquid. The presented approach takes advantage of the hydrogen released as a by-product from an exothermic reaction used in point of care diagnostics devices. This solves one of the critical challenges for portable hydrogen fuel cells, the storage and release of hydrogen gas, and couples with the advantages of paper microfluidic fuel cells. The resulting device operates by capillary action, the supplied sample dilutes the dry-stored electrolytes needed for the fuel cell and to activate the hydrogen generation. The device produces more than $25 \mathrm{~mW}$ in a compact selfcontained design, which to the authors knowledge, is the highest power achieved by any paperbased fuel cell.

This paper-based hydrogen fuel cell holds great promise for powering portable diagnostics as the generated electric power could enable advanced device functionalities. The same liquid sample that is to be analyzed (urine, saliva, water, etc.) could be used to trigger hydrogen generation and start fuel cell operation. Additionally, the disposal pathway of this fuel cell can be similar to that of lateral flow tests. 


\section{Acknowledgements}

J.P. Esquivel acknowledges support from Marie Curie International Outgoing Fellowship (APPOCS - GA.328144) within the 7th European Community Framework Programme. J. Buser and P. Yager were supported by a grant from DARPA DSO/BTO--HR0011-11-2-0007, awarded to Yager at the University of Washington. P. Yager was supported in part by funds from the Department of Bioengineering at the University of Washington. S. Rojas acknowledges financial support from project ENE2013-42322R. N. Sabaté would like to thank financial support received from ERC Consolidator Grant (SUPERCELL - GA.648518).

\section{References}

[1] A.K. Yetisen, M.S. Akram, C.R. Lowe, Lab on a Chip, 13 (2013) 2210-2251.

[2] S. Choi, Biotechnology Advances, 34 (2016) 321-330.

[3] F. Sharifi, S. Ghobadian, F.R. Cavalcanti, N. Hashemi, Renewable and Sustainable Energy Reviews, 52 (2015) 1453-1472.

[4] T.H. Nguyen, A. Fraiwan, S. Choi, Biosensors and Bioelectronics, 54 (2014) 640-649.

[5] L. Nyholm, G. Nyström, A. Mihranyan, M. Strømme, Advanced Materials, 23 (2011) 3751-3769.

[6] S.K. Mahadeva, K. Walus, B. Stoeber, ACS Applied Materials \& Interfaces, 7 (2015) 8345-8362.

[7] E. Kjeang, N. Djilali, D. Sinton, J. Power Sources, 186 (2009) 353-369.

[8] S.A. Mousavi Shaegh, N.-T. Nguyen, S.H. Chan, International Journal of Hydrogen Energy, 36 (2011) 5675-5694.

[9] J.P. Esquivel, F.J. Del Campo, J.L. Gomez de la Fuente, S. Rojas, N. Sabate, Energy \& Environmental Science, 7 (2014) 1744-1749.

[10] R.K. Arun, S. Halder, N. Chanda, S. Chakraborty, Lab on a Chip, 14 (2014) 1661-1664.

[11] S. Lal, V.M. Janardhanan, M. Deepa, A. Sagar, K.C. Sahu, Journal of The Electrochemical Society, 162 (2015) F1402-F1407.

[12] T.S. Copenhaver, K.H. Purohit, K. Domalaon, L. Pham, B.J. Burgess, N. Manorothkul, V. Galvan, S. Sotez, F.A. Gomez, J.L. Haan, ELECTROPHORESIS, 36 (2015) 1825-1829.

[13] V. Galvan, K. Domalaon, C. Tang, S. Sotez, A. Mendez, M. Jalali-Heravi, K. Purohit, L. Pham, J. Haan, F.A. Gomez, ELECTROPHORESIS, 37 (2016) 504-510.

[14] K.H. Purohit, S. Emrani, S. Rodriguez, S.-S. Liaw, L. Pham, V. Galvan, K. Domalaon, F.A. Gomez, J.L. Haan, J. Power Sources, 318 (2016) 163-169.

[15] S.M. Mousavi Ehteshami, M. Asadnia, S.N. Tan, S.H. Chan, J. Power Sources, 301 (2016) 392-395.

[16] L. Zhang, M. Zhou, D. Wen, L. Bai, B. Lou, S. Dong, Biosensors and Bioelectronics, 35 (2012) 155-159.

[17] I. Shitanda, S. Kato, Y. Hoshi, M. Itagaki, S. Tsujimura, Chemical Communications, 49 (2013) 11110-

11112.

[18] C.W. Narvaez Villarrubia, C. Lau, G.P.M.K. Ciniciato, S.O. Garcia, S.S. Sibbett, D.N. Petsev, S.

Babanova, G. Gupta, P. Atanassov, Electrochemistry Communications, 45 (2014) 44-47.

[19] C.W. Narvaez Villarrubia, F. Soavi, C. Santoro, C. Arbizzani, A. Serov, S. Rojas-Carbonell, G. Gupta, P. Atanassov, Biosensors and Bioelectronics, 86 (2016) 459-465.

[20] C. Fischer, A. Fraiwan, S. Choi, Biosensors and Bioelectronics, 79 (2016) 193-197.

[21] Maria José González-Guerrero, F. Javier del Campo, Juan Pablo Esquivel, Fabien Giroud, S.D. Minteer, N. Sabaté, J. Power Sources, (2016).

[22] M.J. González-Guerrero, F.J. del Campo, J.P. Esquivel, D. Leech, N. Sabaté, Biosensors and Bioelectronics.

[23] J. Winfield, L.D. Chambers, J. Rossiter, J. Greenman, I. Ieropoulos, Journal of Materials Chemistry A, 3 (2015) 7058-7065.

[24] A. Fraiwan, S. Mukherjee, S. Sundermier, H.-S. Lee, S. Choi, Biosensors and Bioelectronics, 49 (2013) 410-414.

[25] A. Fraiwan, S. Choi, Biosensors and Bioelectronics, 83 (2016) 27-32.

[26] R. O'Hayre, Fuel Cell Fundamentals, John Wiley \& Sons, New York, 2006.

[27] J. Larminie, A. Dicks, Fuel Cell Systems Explained, John Wiley \& Sons, West Sussex, England, 2003.

[28] L. Carrette, K.A. Friedrich, U. Stimming, Fuel Cells, 1 (2001) 5-39.

[29] J.P. Esquivel, F.J. Del Campo, J.L. Gomez de la Fuente, S. Rojas, N. Sabate, ECS Transactions, 64

(2014) 875-880.

[30] B. Sakintuna, F. Lamari-Darkrim, M. Hirscher, International Journal of Hydrogen Energy, 32 (2007) 11211140.

[31] I.P. Jain, C. Lal, A. Jain, International Journal of Hydrogen Energy, 35 (2010) 5133-5144.

[32] Horizon Fuel Cell, http://www.horizonfuelcell.com/, 2016, Horizon.

[33] Hydrogen Reactor, http://www.brunton.com/pages/hydrogen-reactor, 2016, Brunton. 
[34] PowerTrekk, http://powertrekk.com/, 2016, myFC.

[35] L.K. Lafleur, J.D. Bishop, E.K. Heiniger, R.P. Gallagher, M.D. Wheeler, P. Kauffman, X. Zhang, E.C. Kline, J.R. Buser, S. Kumar, S.A. Byrnes, N.M.J. Vermeulen, N.K. Scarr, Y. Belousov, W. Mahoney, B.J. Toley, P.D. Ladd, B.R. Lutz, P. Yager, Lab on a Chip, (2016).

[36] C. Liu, M.G. Mauk, R. Hart, X. Qiu, H.H. Bau, Lab on a Chip, 11 (2011) 2686-2692.

[37] K.G. Shah, D. Guelig, S. Diesburg, J. Buser, R. Burton, P. LaBarre, R. Richards-Kortum, B. Weigl, PLoS ONE, 10 (2015) e0139449.

[38] J.R. Buser, X. Zhang, S.A. Byrnes, P.D. Ladd, E.K. Heiniger, M.D. Wheeler, J.D. Bishop, J.A. Englund, B. Lutz, B.H. Weigl, P. Yager, Analytical Methods, 8 (2016) 2880-2886.

[39] J.R. Buser, S. Diesburg, J. Singleton, D. Guelig, J.D. Bishop, C. Zentner, R. Burton, P. LaBarre, P. Yager, B.H. Weigl, Lab on a Chip, 15 (2015) 4423-4432.

[40] M. Sema, A. Alemu, A.G. Bayih, S. Getie, G. Getnet, D. Guelig, R. Burton, P. LaBarre, D.R. Pillai, Malaria Journal, 14 (2015) 44.

[41] K.A. Curtis, D.L. Rudolph, D. Morrison, D. Guelig, S. Diesburg, D. McAdams, R.A. Burton, P. LaBarre, M. Owen, Journal of Virological Methods, 237 (2016) 132-137.

[42] J. Singleton, J.L. Osborn, L. Lillis, K. Hawkins, D. Guelig, W. Price, R. Johns, K. Ebels, D. Boyle, B. Weigl, P. LaBarre, PLoS ONE, 9 (2014) e113693.

[43] F.R. Brushett, M.S. Naughton, J.W.D. Ng, L. Yin, P.J.A. Kenis, International Journal of Hydrogen Energy, 37 (2012) 2559-2570.

[44] F.R. Brushett, W.-P. Zhou, R.S. Jayashree, P.J.A. Kenis, Journal of The Electrochemical Society, 156 (2009) B565-B571.

[45] Energizer® 1616 Battery, http://www.energizer.com/specialty-batteries/1616-battery, 2016, Energizer ${ }^{\circledR}$.

[46] Blue Spark ST (Standard) Series, http://www.bluesparktechnologies.com/index.php/products-andservices/battery-products/standard-series, 2016, BlueSparkTechnologies.

[47] 45041 Platinum, nominally $45070 \%$ on high surface area advanced carbon support, HiSPEC тм 13100 , http://www.alfa.com/en/catalog/45041, 2016, Alfa-Aesar.

[48] F.J. Perez-Alonso, D.N. McCarthy, A. Nierhoff, P. Hernandez-Fernandez, C. Strebel, I.E.L. Stephens, J.H. Nielsen, I. Chorkendorff, Angewandte Chemie International Edition, 51 (2012) 4641-4643.

[49] S. Koh, P. Strasser, Journal of the American Chemical Society, 129 (2007) 12624-12625.

[50] Z. Chen, D. Higgins, A. Yu, L. Zhang, J. Zhang, Energy \& Environmental Science, 4 (2011) 3167-3192.

[51] A. Serov, K. Artyushkova, P. Atanassov, Advanced Energy Materials, 4 (2014) n/a-n/a.

[52] M. Shao, Q. Chang, J.-P. Dodelet, R. Chenitz, Chemical Reviews, 116 (2016) 3594-3657.

[53] C. Domínguez, F.J. Pérez-Alonso, M.A. Salam, S.A. Al-Thabaiti, M.A. Peña, F.J. García-García, L. Barrio, S. Rojas, Applied Catalysis B: Environmental, 183 (2016) 185-196.

[54] L. Shui, J.C.T. Eijkel, A. van den Berg, Advances in Colloid and Interface Science, 133 (2007) 35-49

[55] K. Monsalve, I. Mazurenko, N. Lalaoui, A. Le Goff, M. Holzinger, P. Infossi, S. Nitsche, J.Y. Lojou, M.T.

Giudici-Orticoni, S. Cosnier, E. Lojou, Electrochemistry Communications, 60 (2015) 216-220. 